\title{
ELIA
}

Estudios de Lingüística Inglesa Aplicada

\section{ONE GENERATION AFTER THE BILINGUAL TURN: RESULTS FROM A LARGE-SCALE CLIL TEACHERS' SURVEY}

\section{UNA GENERACIÓN DE ENSEÑANZA BILINGÜE: RESULTADOS DE UN ESTUDIO A GRAN ESCALA DE PROFESORES AICLE}

\author{
Francisco Lorenzo \\ Universidad Pablo de Olavide, Spain \\ fjlorber@upo.es
}

\section{Adrián Granados}

Universidad Pablo de Olavide, Spain

agranav@upo.es

\begin{abstract}
The bilingual turn required education systems to undergo structural changes in order to adapt to the new situations. These adjustments included better language training for teachers, the adoption of alternative teaching methods, the increased use of ICT and self-designed materials, the curricular integration of content and language and the creation of competence-based assessment guidelines. In order to evaluate the depth of this transformation and the actual effect that it had on students and schools, a sustained observation covering a sufficiently wide timespan needed to be performed.
\end{abstract}

Two decades after the inception of bilingual education in Andalusia-Southern Spain - this paper will describe the configuration of the Bilingual Program as perceived by the change agents: the school teachers. L1 Spanish teachers, L2 teachers and content teachers adopted different practices and therefore hold slightly divergent opinions. Nevertheless, there exists a consensus on the 
general benefits of CLIL bilingual education. Drawing from their perceptions, which will be presented for each of the above-mentioned aspects, this paper will counter the most recurrent criticisms that CLIL education meets.

Keywords: Bilingual education, content and language integrated learning (CLIL), competence-based learning, teachers' perception, Andalusian Bilingual Program, Andalusia.

\section{Resumen}

$\mathrm{El}$ auge del bilingüismo ha hecho necesario que los sistemas educativos experimenten cambios estructurales para adaptarse a las nuevas situaciones. Entre estos ajustes se encuentran la mejora de la formación lingüística del profesorado, la adopción de métodos docentes alternativos, el aumento del uso de las TIC y de materiales propios, la integración curricular de lenguas y contenidos y la creación de criterios de evaluación basados en competencias. Para evaluar la profundidad de esta transformación y el verdadero efecto que ha tenido en los estudiantes y los centros educativos, se necesita una observación prolongada que abarque un periodo de tiempo lo suficientemente amplio.

Tras dos décadas de educación bilingüe en Andalucía - la comunidad autónoma del sur de España - este artículo pretende describir la implantación del Programa Bilingüe tal y como la perciben los agentes del cambio: el profesorado. Los profesores de Lengua Española (L1), los de Lengua Inglesa (L2) y los de áreas no lingüísticas han adoptado diferentes prácticas y manifiestan por tanto opiniones ligeramente distintas. Sin embargo, existe un consenso generalizado en cuanto a los beneficios que ofrecen la metodología AICLEy la educación bilingüe. En este artículo presentaremos las percepciones del profesorado del Programa Bilingüe de Andalucía sobre cada uno de los aspectos anteriores y, basándonos en estas, defenderemos la metodología AICLE de las críticas más recurrentes de sus detractores.

Palabras clave: Educación bilingüe, aprendizaje integrado de contenidos y lenguas extranjeras (AICLE), aprendizaje por competencias, Programa Bilingüe de Andalucía. 


\section{Introduction}

Over the years, European language policies have promoted multilingualism to fulfil goals on language development, multiple identities and EU citizenship rights. One of these policies aimed at increasing the number of languages of schooling, drawing on the former experience of elite schools also known as European schools (Baetens, 1993). Therefore, the Content and Language Integrated Learning (CLIL) movement was not a genuine innovation in the nature and conceptualization of language teaching, but it has certainly been a colossal policy in implementation breadth. Transforming continental education called for reflection sustained over the years, which is partly the reason for the CLIL academic craze in the form of scholarly publications. Part of this long monitoring took the form of regional, national and international surveys which evaluated the new policies. Only in Spain, admittedly among the most hectic countries in bilingual implementation, one can select the following research studies presenting or discussing learning outcomes: Abello-Contesse et al. (2013), Heras \& Lasagabaster (2015), Sotoca (2016), and Rascón \& Bretones (2018). In line with the present study, Pavón \& Rubio (2010), Ruiz et al. (2011), Hüttner et al. (2013), Lasagabaster \& García (2014), Pavón et al. (2014), Moore \& Lorenzo (2015) and Skinnari \& Bovellan (2016) also discussed teachers' beliefs and reactions. All this research activity happened against the background of European research, as in Coonan (2007), De Graaf et al. (2007) or Coyle (2008).

However, the timespan for any educational innovation to reveal its effects is long and one can only see the real extent of change after several decades, once false starts, drawbacks and investment volatilities finish to mold programs. CLIL has come of age now. The first CLIL 
programs started in the very late 20th century; enough time for stakeholders and participants to take a stance on its long-term effects. In Spain, for example, the language level demanded for teachers to participate in the program was CEFR B1/B2. This is now the language level that bilingual students reach by the end of compulsory education, at the age of 16 . What was demanded from teachers twenty years ago is mostly achieved by students now. Long-term observations like this inform of real transformations in education, such as gains in language capital across generations rather than a slight evolution along the years. CLIL involved other major changes: new languages of instruction, alternative teaching methods, competence-based curricular design, textual education and curricular integration-and ultimately created a new model for the development of multilingual competence and multicultural education. In addition, group organization, curricular design and teachers' profile change substantially with bilingualism.

Even if research has been abundant, this paper adds a twist to the state of the art: firstly, the acknowledgement that a generation has gone by and that researchers need to look back in time in order to rightfully appreciate the extent of the change. Secondly, the unusually large scale of the survey regarding the number of informants (1,101). Views from informants are usually scarce and surveys rely on their willingness to contribute, which sometimes produces skewed results. The collaboration with the Regional Board of Education (Agencia Andaluza de Evaluación Educativa) provided a high turnout of participants. The authors were granted permission for data access, statistical analysis and a scholarly interpretation of results. A report with raw survey data was made public and available online (Lorenzo, 2019). 
Of all the information that the authors were provided with (performance rates in content, L1 and L2 courses, Socioeconomic status information, etc.), we decided to select teachers as the main source of information. As it could not be otherwise, many of the CLIL innovations fell on the shoulders of teachers-who had to rethink themselves as content experts, facilitators, instructors, assessors and other professional roles. This paper intends therefore to survey their views, reactions and global stance on the program to measure the dimension of educational change. Therefore, it is the voices of teachers which will be presented here and assess the program: achievements, challenges, strengths and potential improvements.

\section{The Study}

\subsection{Objectives}

The general objectives of the present study are:

a) The description of the configuration of the program (resources, coordination mechanisms, language immersion, distribution of skills, and teachers' roles, language profile and methodologies) as perceived by CLIL teachers.

b) The analysis of the strengths, weaknesses, opportunities and threats (SWOT analysis) of the program as perceived by CLIL teachers.

\subsection{Research Context}

Andalusia is a southern region in Spain, with a population of around 9 million people, a school network of over 4,000 schools and a teaching force of over 100,000 professionals. The bilingual sections of this region were evaluated in a seminal study, which was the first to 
One generation after the bilingual turn: results from a large...

track progress in multilingual European education (Lorenzo, Casal \& Moore, 2009). At present, Andalusia has 1,079 bilingual schools: 598 bilingual primary schools and 481 bilingual secondary schools.

\subsection{Survey Participants}

Two requirements were set for the sample design: only SpanishEnglish bilingual schools were to be considered, and the population of students in their final year should be larger than 5. For stratification purposes, the following variables were also taken into consideration: school status (state/private), location across the regional geography and socioeconomic status. A sample of 29 schools from each stage (primary or secondary) was finally selected, rendering a total of 58 schools.

\subsection{Instruments}

A questionnaire targeting school functioning and teachers' perception was designed and distributed in June 2017. It was created in four versions, one for each teaching profile: Spanish Language (L1) teachers, English (L2) teachers, content teachers (CTs) and school coordinators of the Bilingual Program. The questionnaire for CTs is provided as an example in Appendix I. The number of questionnaires was 1,101: 377 for L1 teachers, 238 for L2 teachers, 428 for CTs and 58 for bilingual coordinators (BC) (there is just one bilingual coordinator per school).

The questionnaires were composed of two sections: closeended questions and a SWOT analysis (Strengths, Weaknesses, Opportunities and Threats). The close-ended questions asked teachers to assign a value from a 6-point scale to statements regarding their language training, teaching methodology, 
resources, curricular integration, degree of language immersion, evaluation, students' competences, and overall satisfaction. The results from the first section will be presented in part 3, and part 4 will be devoted to the SWOT analysis.

\section{Teachers' Perception of the Andalusian Bilingual Program}

This section will cover the perception that Spanish (L1) teachers, English (L2) teachers and content teachers (CTs) have of their language training, teaching methodology, resources, curricular integration, degree of language immersion, evaluation, students' competences, and overall satisfaction. The average value from the 6point scale that each group selected for each area will be commented in the text. To prevent duplicate values, the figures will only display the values that all three groups (L1, L2 and CTs) selected on average.

\subsection{Language Training}

The minimum level of English for CTs to enter the Andalusian Bilingual Program is presently a CEFR B2 level, although new policies aim to upgrade this level to $\mathrm{C} 1$ by the year 2020. Language competence is indeed one of the biggest concerns among participants, as shown by the SWOT analysis discussed later. Overall, all the teachers follow some kind of language training, either as part of formal courses or through the practice of English in everyday activities. For CTs, audiovisual material is the most popular resource to practice their receptive skills (it receives and average value of 4.95 out of 6). Foreign press (3.98), literary works (3.57) and research works and essays (3.50) in their L2 also display high incidence scores. Regarding productive skills, exchanges with L2 native speakers take the lead (3.62); whereas attending speaking lessons (2.94) and traveling abroad (2.93) constitute less common activities. 
Nevertheless, a considerable proportion of teachers are undergoing formal training in order to achieve the levels C1 or C2.

L2 teachers also pursue their language updating, although their habits differ from those of CTs. Their most frequent activity is undoubtedly watching television and movies in their English original version (4.99). Reading literary works (4.34) and foreign press (4.08) also present high incidence scores, followed by reading essays or scientific works in their L2 (3.34). For the update of their productive skills, L2 teachers favor meeting with native speakers (4.28). Attending speaking lessons is almost as frequent for L2 teachers (3.05) as it is for CTs (2.94). Nevertheless, L2 teachers' tendency to travel exceeds CTs' in 0.6 (3.53 and 2.93, respectively). Finally, their attendance to preparatory lessons for C1 or C2 certification exams is also high (3.46). Figure 1 shows the percentage of CTs and L2 teachers that selected each value.

Figure 1: Average language training followed by Content Teachers and L2 teachers from the Bilingual Program

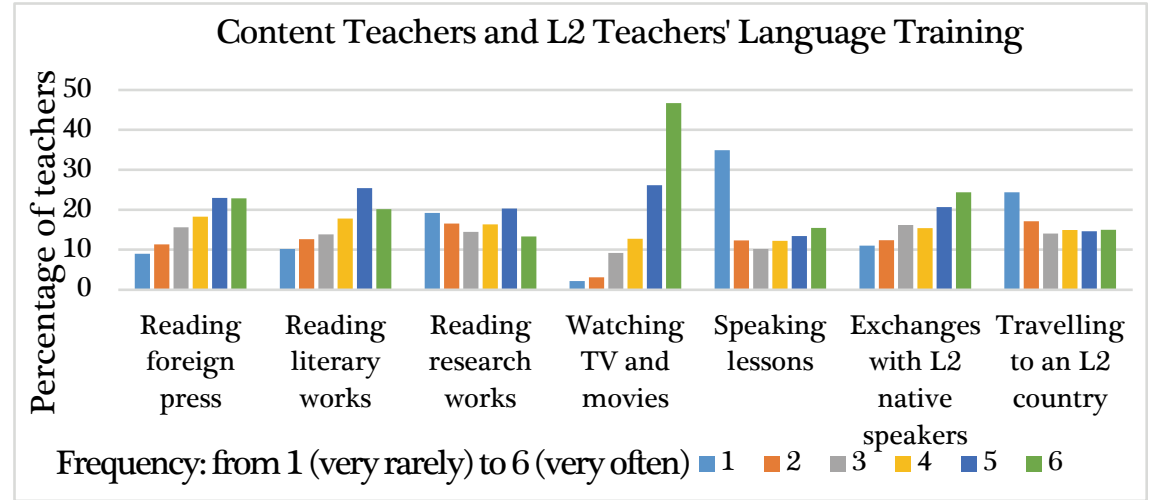

A lack of language skills has deterred bilingual implementation for a number of years. All parts acknowledge that the 
program commenced with insufficient language resources, which were partly balanced with native language assistants. New recruiting policies which valued language competence opened new job opportunities for emerging graduates with a flair for languages. The new program benefited from brand new access to online content and high-tech aids, which prompted new cultural habits. These strategies rank among the most widely used now: as Figure 1 shows, watching original movies and reading for pleasure or for professional reasons stand out as common habits. They rank higher than other formal learning experiences such as refreshment courses and formal language tuition. In the coming years, there will be major pressures for the network to expand and, once again, human resources are likely to be scarce. Time will tell whether schools yield to the interest of stakeholders, who crave for expansion by any means, or whether quality standards will prevail. The new Official Multilingual Plan (2016-2020) points to C1 or above as the threshold for future teacher recruitment. Whether this inclination is brought to completion needs to be monitored by future surveys.

\subsection{Teaching Methodology: Communicative Teaching and Task- Based Learning}

A well-known weakness of the system researched is its traditional teaching methods. Although the national educational standards are comparable to the average OECD records, Spanish education features very low scores in aspects which imply poor understanding of the teaching-learning process (OECD, 2014). Spanish teachers are among the world's strongest advocates of transmission principles: teachers are the dispenser of knowledge and truth, which in the case of L2 teaching involves a very traditional grammar-orientated approach. Over the years, this has left what was once called generations of non-communicators. PISA, PIRLS and TALLIS reports confirm this vision (OECD 2003, 2018). 
The Bilingual Program was expected to bring along innovations in this field, more precisely a greater consideration for cross-curricular approaches, more communicative (and task-based) teaching and more competence-based assessment guidelines. Practitioners soon understood that teaching content in a second language (mathematics or history, for example) demanded a less language-centered approach. In response to whether the program has meant a change in the teaching methodology of their disciplines, the majority of Spanish Language teachers affirms innovation has occurred in the form of a more communicative approach (4.07). The same answer is provided by English teachers (4.71). As regards task-based learning (TBL) and cross-curricular projects that encourage participation and meaningful learning, Spanish Language teachers (3.94), English teachers (4.25) and CTs (4.14) use these methodologies since the program was implemented. The average of these responses are displayed in Figure 2.

Figure 2: Average compliance with Task-Based Learning and Communicative Teaching by all teachers in the Bilingual Program

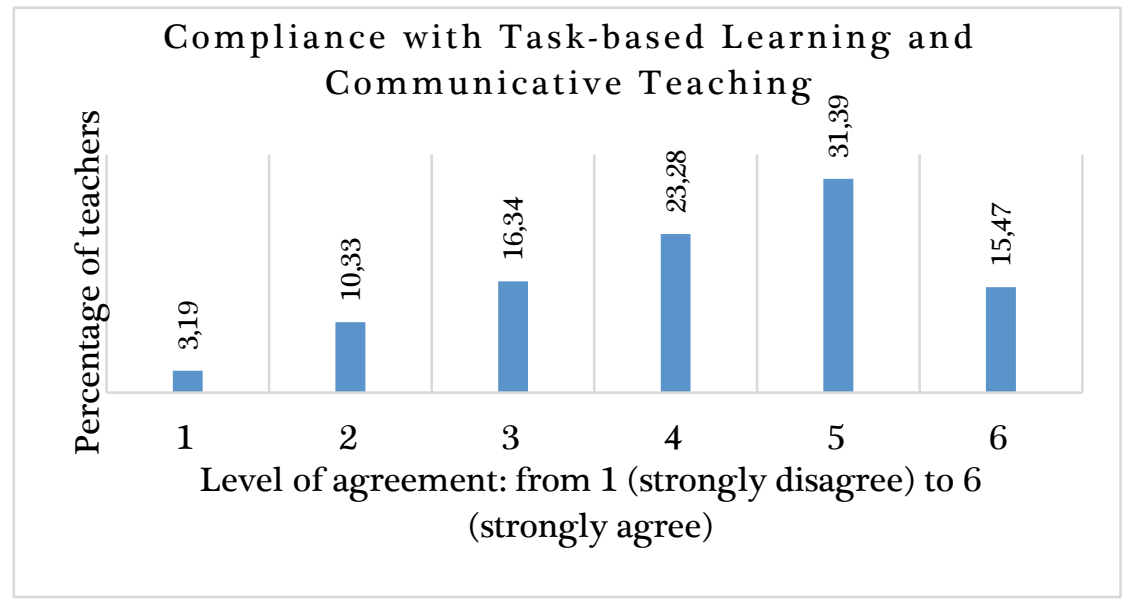


These scores make us entertain the idea that CLIL has mobilized new teaching methods, not in the L2 realm alone but for Spanish L1 too. This factor could account for the similar responses that content teachers give in the survey, who-even if somewhat mildly-feel their teaching is more task-based now. As a matter of fact, the administration has made available a template of innovative projects which adhere to task-based principles, which readers may want to browse for inspiration (Junta de Andalucía, 2011).

However, we should be wary of these promising results regarding the method renovation allegedly triggered by the Bilingual Program. CLIL is no magic wand and it may be the case that bilingual schools are self-selecting the teachers who are more ready to team up and explore new avenues. In Andalusia, participation in the bilingual network is partly a school decision, i.e. a bottom-up move albeit helped by bonuses (fewer teaching hours, better facilities and equipment, native assistants, etc.). Still, it may be the case that teachers more prone to change are more in favor of CLIL.

\subsection{Resources}

Since its inception, bilingual education has been seriously hampered by the lack of appropriate materials. Traditional resources such as textbooks did not meet the needs of bilingualism - if they were available at all (see Moore \& Lorenzo, 2015, and Lorenzo \& Trujillo, 2017, for more details on materials availability in the research context). Workbooks, videos and recordings with course content and mixed-ability tasks were rare to find. In spite of ad-hoc solutions in the form of bilingual lesson- 
plan libraries, teachers of all courses turned to the internet for resources. This was a daunting experience for teachers, who had traditionally relied on commercial textbooks. The provision of free textbooks to all the students is a policy at the research context. However, these textbooks are not appropriate for bilingual schools. That situation frames the responses in Figure 3 below, regarding the high participation of all teachers in designing teaching materials. The scores for teaching materials design are 4.18 for L2, 4.05 for CTs, and 3.51 for L1. When asked about the innovative nature of the materials they use, the answers are once again affirmative. The values obtained are clear in this respect, for Spanish Language teachers (4.30), L2 teachers (4.78) and CTs (4.81) alike. There is, however, a strong demand for more time to be devoted and officially recognized for this purpose, since the actual amount is considered insufficient (2.11).

The promotion of Information and Communications Technology (ICT) is perceived to be a direct consequence of the Bilingual Program (4.46 for L2, 4.84 for CTs, and 3.95 for L1), in accordance with the new role played by the internet. Conversely, the European Language Portfolio (ELP) seems to have fallen into disuse: neither L1 (3.06) nor L2 teachers (2.57) appear to find it useful. In its early days, the ELP was a suitable instrument for the dissemination of CEFR levels and their descriptors, together with the principles of the Council of Europe's policy-multiple identities, competence-based learning, multilingualism and multiculturalism. Nevertheless, the natural integration of these principles within the curriculum may have reduced the need for the European Language Portfolio (ELP). 
Figure 3: Average use of self-designed materials and ICT by all teachers from the Bilingual Program

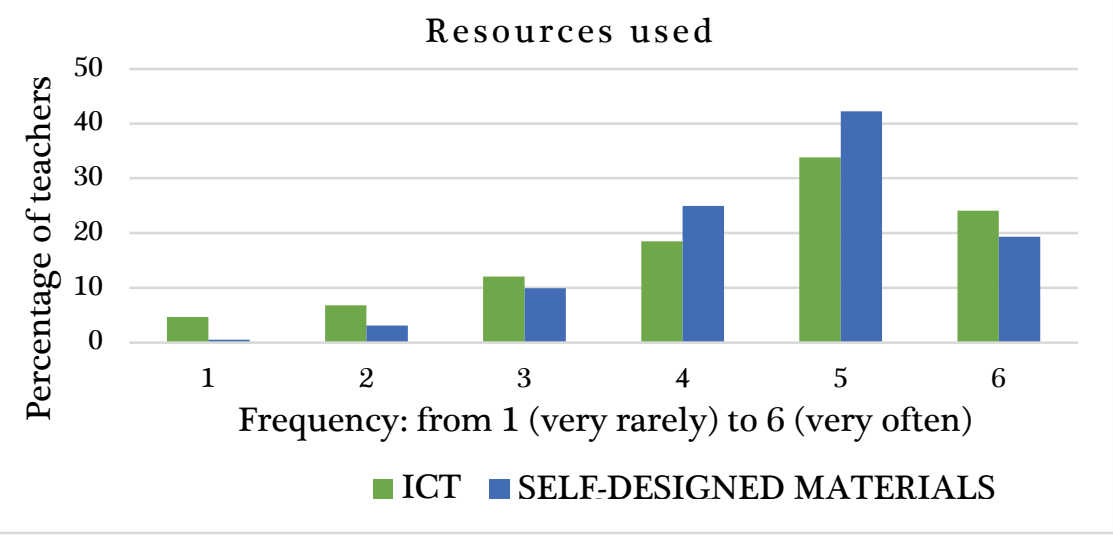

\subsection{Integration of Language and Content}

CLIL revolves around the idea of integration; that is, the concept that some language texture lies under the knowledge structures that shape disciplinary content (history, mathematics or that of any other sort). With this idea in mind, teachers had to map out the language structures, vocabulary, functions and notions of the content they present to their pupils (i.e. what vocabulary items, expressions and grammar points their students need to know in order to learn ecosystems in science, algebraic numbers in mathematics, etc.).

Several curriculum types incorporate this principle: genremaps and whole-school language plans, among others. Bilingual teacher teams were requested to adhere to this principle for curriculum organization and present an integrated plan for language and content, which received the label curriculum integrado de las lenguas o proyecto lingüístico de centro. This was core for the bilingual network and set teachers' collaborative work 
One generation after the bilingual turn: results from a large...

in motion. Results from their putting their heads together is shown in Figure 4.

Figure 4: Average use of a content and language integrated plan by all teachers from the Bilingual Program

Use of a Content and Language Integrated Plan
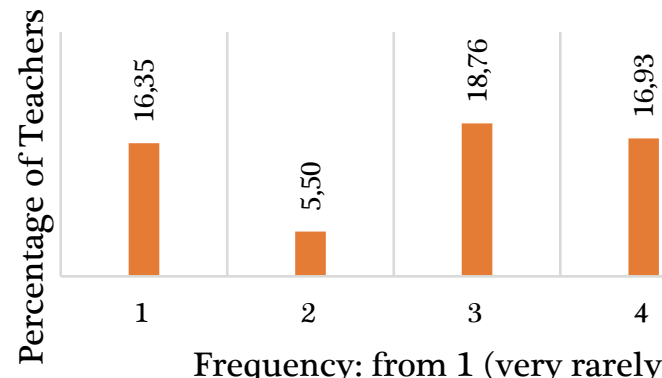

ì

3

4

5

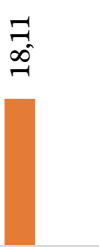

6

Frequency: from 1 (very rarely) to 6 (very often)

Deep down, what this amounted to for CTs was to incorporate language education as part of their content responsibilities. One further consequence of this content and language integrated plan was the organization of L2 and L1 reading and writing tasks in all classes and therefore the positioning of texts as major components in content courses: mathematics, history, etc. The end result may be students with a better command of cohesion and coherence in text construction.

\subsection{Immersion Levels}

A major criticism of bilingual programs in Spain is that immersion levels are low, i.e. that L2 contact hours are scarce and that English is used in small proportions (Lorenzo, Casal \& Moore, 2009). A popular view on bilingual schools holds that L2 should be used at all times, as in full immersion. The past research shows that on many occasions bilingual schooling does not even reach partial 
immersion levels as in two-way bilingual programs. While the second language (English) is used at all times for the English courses, in content courses immersion levels range from 20 percent of the time (one fifth of content teachers) to 80 percent of the time (approximately 12 percent of content teachers).

Several factors account for these figures: many teachers (especially in primary education) might switch from L2 to L1 for particular content lessons for fear that students get lost and learning deficits occur. As part 4 from the present study shows, the sink or swim threat is often present in the mind of teachers. The result is that content courses (i.e. Science) may not be taught in an L2 throughout. The program's flexibility regarding teachers' individual decisions-especially in terms of classroom interaction-renders this situation very common. Nevertheless, L2 teachers use mostly only English during their lessons, creating a true immersion environment (aprox. $75 \%$ of the time, on average). This is helped by native language assistants (above $80 \%$ of the time), who represent one of the main pillars of the program. The immersion levels reached by these two agents are much higher than those achieved by CTs (only around $50 \%$ of the time, on average), which are shown in Figure 5. Therefore, as L2 contact is a fundamental factor in language acquisition, the bilingual scheme could deliver higher competence results should the new language be used alone. Immersion levels tend to remain stable in secondary education, when students have been involved in the program for a number of years and learning is not believed to be compromised. Future higher teacher qualifications will help immersion too. 
One generation after the bilingual turn: results from a large...

Figure 5: Average L2 use in bilingual content courses

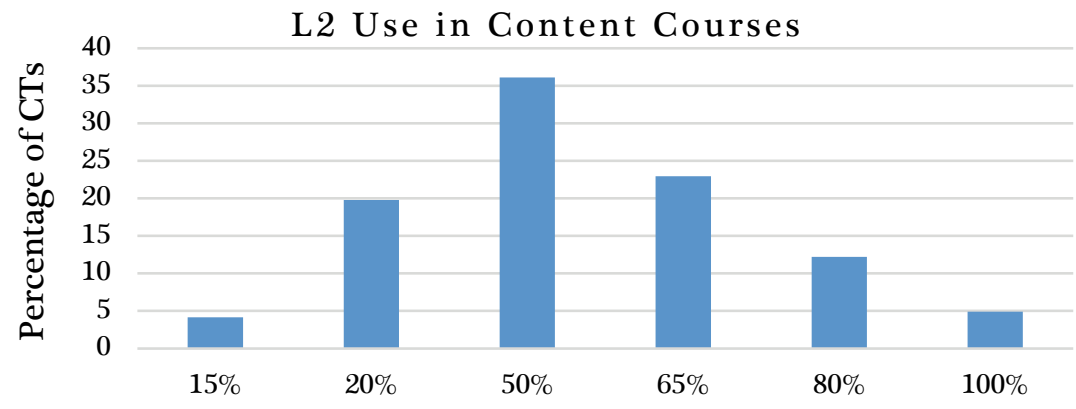

Proportion of L2 use in class

\subsection{Assessment}

From the beginning of the program, evaluation has been a matter of concern for teachers (see, for example, Pavón \& Rubio, 2010). This was partly because they were unsure as to how to blend traditional marking with bilingual principles. This affected a number of issues: the language in the exam, the extent to which language errors should be considered in marking or, even more critical, how learning could be properly assessed when students used English-a language they do not fully control—during exams.

As it can be seen in Figure 6, teachers did feel the need to join forces for assessment purposes. L2 and content teachers report mutual collaboration as they intended to provide a fair assessment of their students' progress. Nevertheless, as part 4 from this study shows, teachers of all disciplines still feel the need for further coordination. We think this shows the effects of teachers' introspection and reflection on their own practices. The data in 
Figure 6 (which displays the responses of the three groups on average) report changes in assessment as a result of their collaborating in exam development. In fact, the results point to the use of evaluation guidelines based on common criteria in Spanish Language (4.35), English (4.25) and content courses (4.38). However, it remains to be seen whether these agreements ultimately involve formative and inclusive assessment.

Figure 6: Average assessment coordination in bilingual schools by all teachers from the Bilingual Program

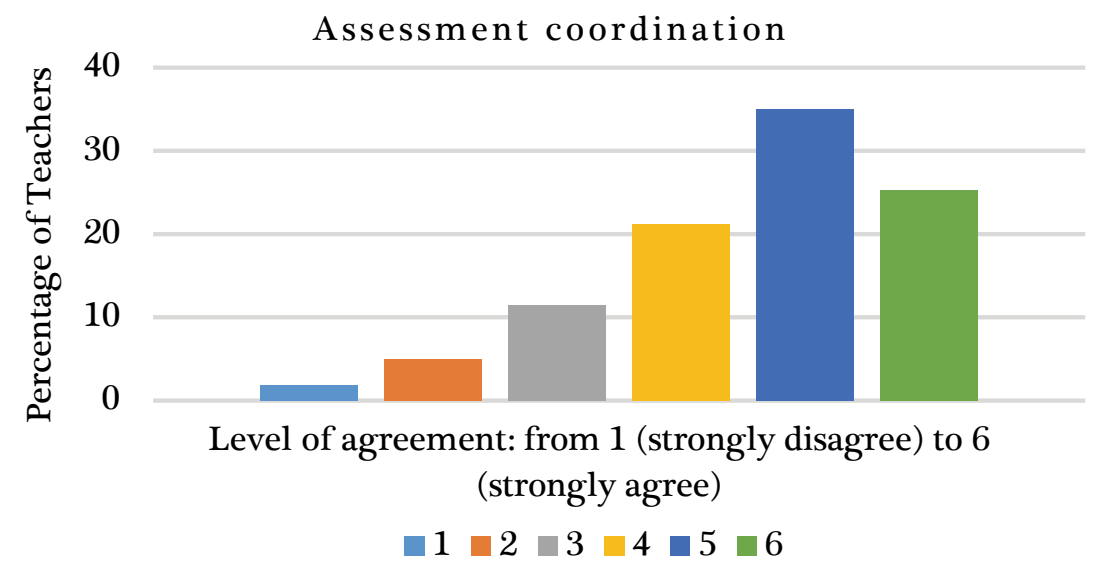

\subsection{Competences}

CLIL was devised for increasing students' language level. Tests have already proven CLIL's effectiveness over the years, but teachers' views may also give insights on the program. They all agree that language competence has risen, which is not a surprising response. However, what we feel is more noteworthy is that L1 and L2 teachers share the same view. During the first years of CLIL implementation, L1 teachers tended to frown upon the program, as English was 
One generation after the bilingual turn: results from a large...

feared to eat away Spanish. Now, there is a strong belief that the program offers benefits for both L2 and L1. This is supported by the results of diagnostic tests too (see the full report in Lorenzo, 2019), where scores of L1 written expression are higher in bilingual students.

The program has a clear positive effect on learning, as it is proven by diagnostic tests. This section adds to that evidence the teachers' perceptions, who confirm the increase in both L1 and L2 knowledge in a bilingual situation. In particular, teachers agree that the program benefits oral expression and comprehension in the Spanish language (3.88) and, without a doubt, in the English language (4.77). CTs are of the same view (4.36), and similar results are obtained for written expression. Figure 7 shows the average of the three groups' perceptions.

Figure 7: All teachers' perception of students' L1 improvement

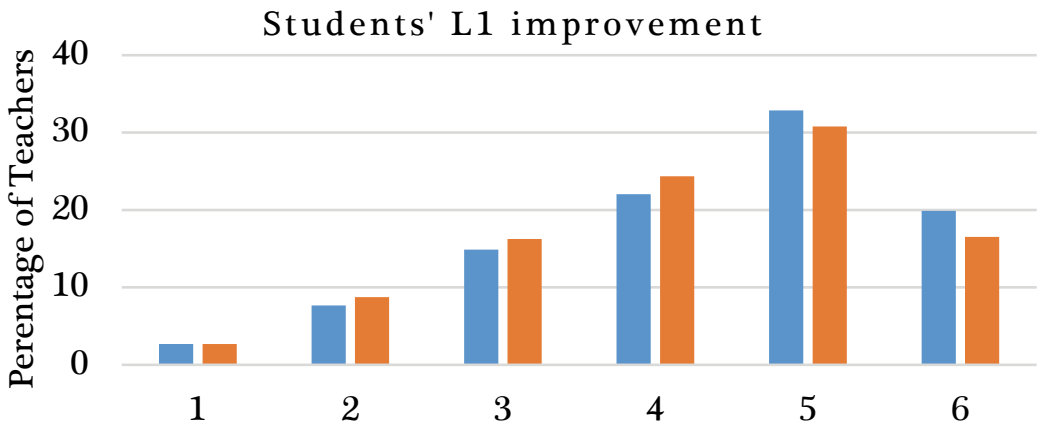

Level of agreement: from 1 (strongly disagree) to 6 (strongly agree)

- LISTENING \& SPEAKING READING \& WRITING

There are however contradictory opinions as to the effects of second language use on content learning. CTs' answers are spread 
all over the six points on the scale and even the end points, which mark very negative and very positive responses, receive scores. None of the available responses reaches 25 percent of agreement, and the average score for this item is 3.24. We would need to further look at CLIL effects in this regard. Perceptions may be affected by a large number of factors: content course, age, school year, students' levels, etc. A large number of studies have researched the effects of bilingual education on general course learning, and they have provided conflicting results. Fernández-Sanjurjo et al. (2017), for instance, indicate content loss in primary science courses via L2 English. Dallinger et al. (2013) point out that the same amount of history content (in secondary education) is learned, but that more time is needed to cover the lessons in CLIL groups (see also Lorenzo, 2017, for CLIL in History; and Jäppinen, 2005, and Surmont et al., 2013, for evidence of no content loss in CLIL in Maths). However, all these results cover individual lessons or short-term periods. The full report that the present research is based on found no learning differences in bilingual and non-bilingual schools as regards history teaching in secondary schools. Being a large-scale study, this may indicate that long-term content learning was not affected. Replications in other territories are essential before we can envisage the real effects of CLIL.

\subsection{Overall satisfaction}

Surveys often include questions on the participants' overall impressions. Even if the interpretation of these questionnaire items is imprecise, results may help researchers to form an opinion on the real assessment of educational programs, here the bilingual scheme. Teachers of all courses react in a rather similar manner. These are the means for each sector: 4.43 (L1 teachers), 4.54 (L2 
One generation after the bilingual turn: results from a large...

teachers) and 4.35(CTs). As a whole, they offer approving reactions to the program and a positive general assessment, as it can be seen in Figure 8, which shows the responses of the three groups on average.

Figure 8: All teachers' overall satisfaction with the Bilingual Program

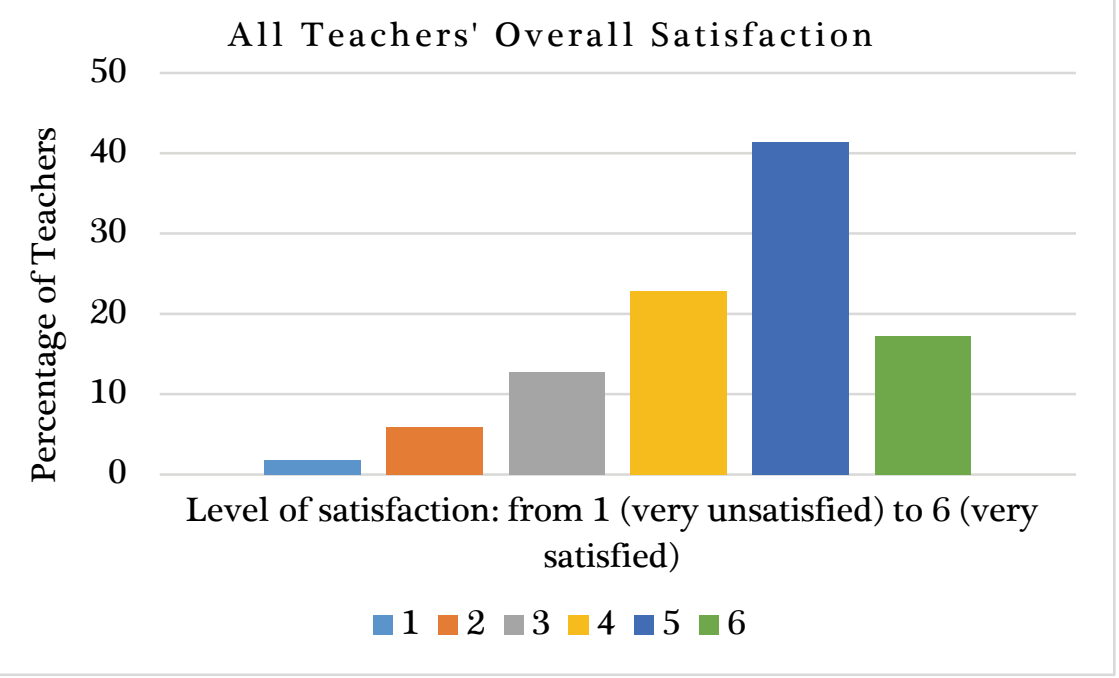

This does not necessarily mean sweeping support from all participants. More than one third of the respondents are not enthusiastic about the program and a larger part of content teachers have reservations, as is shown by the distribution of responses. Having said that, it should be noted that the lowest points in the scale receive almost no support. We tend to interpret all these data as some sort of acknowledgment that, despite implementation difficulties, the program receives full support after some twenty years from its inception. Bilingual schooling has not been fancy innovation but real transformation, which many believe has come to stay. 


\section{Content Analysis}

Teachers' questionnaires included an open-ended section where respondents had to express reactions in a SWOT-style manner. Approvals and criticisms were categorized via content analysis, and a sequence of the most common themes was selected. The most common claims appear below, followed by brief comments. Most respondents demand better human resources, compliance with methods compatible with bilingual education and a better understanding of the teaching-learning processes in bilingualism.

- Reduction of teaching hours: teachers find bilingual lessons harder to plan. They often admit to be feeling overwhelmed by time pressure and overloaded with new bilingual materials development.

- More language assistants: language assistants are very much appreciated. They provide extra native input for classroom interaction and are cherished by students. Nevertheless, some teachers mention their training should be improved.

- Teaching materials: more resources are needed. Many teachers request user-friendly materials banks with lessons ready to go.

- Teacher training: teachers need teaching training plans for technical and language improvement. Teachers are aware of their own technical limitations as CLIL teachers.

- Curricular diversification through the implementation of several bilingual tracks and strands. even if teachers are against segregation, different tracks are considered necessary in order to make bilingual education accessible to students form all backgrounds and levels. Teachers report the serious concern that students may be excluded from the 
bilingual mainstream and that bilingual education may cause learning deficits too.

- Coordination and team work facilitation: bilingual education demands that teachers coordinate their work. Cooperation is needed for syllabus construction, materials sharing and the creation of compatible methods and assessment guidelines. Time should be provided within the school schedule for regular meetings.

- Further teaching hours for content courses: teachers feel they need more time to cover academic content in an L2 and need extra hours for regular content teaching for students to reach similar content learning levels as those in the mainstream.

\section{Discussion}

The bilingual turn in Europe has now come of age. If one generation covers a rough period of between 20 and 30 years on average, as sociology holds, CLIL is on the verge of reaching generational proportions. It certainly has in our research context, where the first pilot studies began in 1998 and students who started primary education in state bilingual schools have already completed post compulsory education (Pérez, Lorenzo \& Pavón, 2016). With over one thousand schools implementing bilingualism and over four hundred thousand students, the experimental phase is definitely over. Society at large has been attentive to the program and has either raised doubts or embrace the move. The media followed suit. Op-ed pieces and reports have dotted national press over the years. El Pais alone-the most global press journal in the Spanish-speaking world-has produced at least three full features on the new multilingual schools. From scholarly fronts (e.g. Banegas, 2012; 
Carro et al., 2016; or Codó \& Patiño Santos, 2017), many colleagues have raised concerns and at times overtly criticized CLIL and their consequences. There were grounds for major concerns and, in this final discussion, we intend to list them and put them into perspective. Some counterarguments will also be presented.

-CLIL as evangelical: Some researchers held that CLIL was being embraced without a critical attitude. Teachers were evangelized and sometimes did not know what was expected of them (Banegas, 2012). It is true that the bilingual seal on school facades was in itself a signal of prestige and modernity and that many school communities found it irresistible. However, this argument often ignores the fact that language skills were the major deficit in the local education system. Decisions were made on the certainty that no innovation could worsen the state of second language education in Spain (European Commission, 2013). In addition, the whole process of schools becoming bilingual came along with major investment in terms of human resources, new recruits with proper language skills and better working conditions in the form of reduction of teaching hours. No wool would be pulled over the eyes of teachers; as the figures of this latter survey show, they can be critical if they need to. Indeed, the data in the present study feature that teachers can be both supportive and critical at once.

-CLIL as neoliberal: Many also thought that CLIL programs were turning language into a commodity. To this, it must be added that languages are a substantial part of social life and, as such, they are-for better or worse-valued in monetary terms. Language as capital is not new in critical linguistics. For instance, Relaño denounces "the commodification of English in the global era, namely, the value assigned to English as a marketable skill” (Relaño, 
2015:132). Codó \& Patiño Santos (2017) openly hold that CLIL embraces neoliberal trends. These criticisms resent the symbolic value of languages and denounce that CLIL promotes linguistic discrimination and linguicism. However, languages have more than symbolic value these days. Orthodox Marxist theory has set the value of human capital through education and compared this asset to other sort of commodities, state property for instance. There is nothing wrong and certainly nothing new in regarding language as a major asset for the increase of cultural capital, less so if the language at stake is a lingua franca. The usefulness of CLIL as a medium of instruction is proven by the increase in language competence that followed CLIL implementation in many places, this research context included (as proven by diagnostic tests and the perception of the teachers surveyed in this study). All surveys that these authors are aware of report language learning gains, most of them at no cost of content learning.

-CLIL as segregative: surveys typically put social variables into their equation to assess results; after all, socioeconomic status is often the variable that best predicts learning outcomes (Block, 2013). That social class has some bearing on language learning is clear: it was the elite private schools which started multilingual education. Somewhat paradoxically, social discrimination was not an issue in applied linguistics when European schools catered to the selected few in Brussels, for instance (Baetens, 1993). However, this has become an issue now that multilingual education has spread to state school networks. One could argue that, in selective education systems-Spain's selective rates are record high with almost one third of dropouts in compulsory education-, innovations will find it hard not to be marked by this selective spirit. When bilingual 
strands were arranged, many students were excluded, but certainly not on social grounds. Parents always had a say and, anecdotally, when bilingual vacancies could not cover the demand, lottery systems were devised for selection. However, some models may have been not only selective but also segregative. For instance, in some Spanish regions, students who do not hold a B1 level certification in early adolescence are excluded from the CLIL strands, and parental major investment in their kids' language capital at an early age secures them a safe place in privileged multilingual groups. We feel that this twofold policy for alleged higher-level and lower-level students may dent equity in state schools. In this survey, teachers take an inclusive stance and favor the implementation of a bilingual model open to all students. Nevertheless, they admit to struggle with mixed-level classes and claim that poor previous levels can sometimes stand in the way of learning. We also want to openly oppose the belief that CLIL does not work for students from low SES backgrounds (Carro et al., 2016). We find that research ideologically loaded. From the teachers' reports, we conclude that they would hardly admit such scenario. Instead, they are found to support the multilingual opportunities that the CLIL turn offered to remote schools in the rural and least privileged areas.

\section{Conclusion}

Innovations may not succeed in education. True innovation demands social and school cohesion, economic support, some faith in the administration and the defeat of many vested interests—overt and covert. Education is the perfect arena for the replication of social differences; the realm in which new generations of uneducated can be nipped in the bud and prevented from ascending the social ladder. Language education has always been core in social 
One generation after the bilingual turn: results from a large...

discrimination; systemic functional linguistics has proven so for the L1 in the UK and immersion studies for the L2 in the USA.

At the turn of the century, with globalization and digital communication, many teachers believed that weak communicative approaches could not prepare younger generations for supranational citizenship, global mobility and intercultural development. As it is widely known, it was the development and preservation of these rights which fostered European bilingual programs. From the perspective of the sociology of language, the CLIL move was a breath of fresh air. It also altered unexpected aspects of school life: classroom interaction, professional promotion, assessment, and school organization, among others. This paper has attempted to present the views of many professionals who opted for the new ways of bilingual education in a mostly monolingual area.

CLIL is now naturalized and has become an essential part of everyday life in schools. This paper has signaled some threats to the program even in its adult stage, a few decades after its inception. The first peril relates to the expansion of the school network that many demand, for which there may not be enough human resources. It is commonly believed that a bilingual network increases the education budget dramatically, but that is not the case. However, it requires new skills from teachers-second language competence-, which may not be available at a specific point in time. Administrations need technical advice on how to make the most of the available human capital, and administration and research are often disconnected. The second threat is to find a balance between what innovation labels bottom-up and top-down moves. Individual schools and regional education systems need to feel autonomous for decision making in carving their best model of bilingual schools. 
However, these decisions are often ill-informed. In a top-down move, the administration should clearly identify best practices from hallmark schools and provide a clear model which can be replicated. Without this, bilingual education can be optimal in some schools and disastrous in others. Our expectation, or perhaps our hope, is that time will be on the side of multilingual education and that those countries which were once at the bottom of international educational rankings will show more acceptable outcomes.

\section{Acknowledgments}

This research was supported by the Spanish Ministry of Economy \& Competitiveness (research grant FFI2016-74885-P) and the Spanish Ministry of Science (research grant FPU18/02673).

The data used in this research has been provided by the Agencia Andaluza de Evaluación Educativa (the official department for educational evaluation). We thank all the teachers who participated in the survey; without their cooperation, this study would not have been possible.

\section{References}

Abello-Contesse, C. Chandler, P. López-Jiménez, D \& Chacón-Beltrán, R. (2013). Bilingual and Multilingual Education in the 21st Century. Building on Experience. Bristol: Multilingual Matters. https://doi.org/10.21832/9781783090716

Baetens Beardsmore, H. (1993). European Models of Bilingual Education. Clevedon: Multilingual Matters.

Banegas, D. L. (2012). CLIL teacher development: Challenges and experiences. Latin American Journal of Content \& Language Integrated Learning; 5(1), 46-56. https://doi.org/10.5294/laclil.2012.5.1.4

Block, D. (2013). Social Class in Applied Linguistics. London: Routledge. https://doi.org/10.4324/9781315871141

Carro, J. M.; Cabrales, A. \& Anghel, B. (2016). Evaluating a bilingual education program in Spain: the impact beyond foreign 
One generation after the bilingual turn: results from a large...

language learning. Economic Inquiry, 54(2), 1202-1223. https://doi.org/10.1111/ecin.12305

Codó, E. \& Patiño-Santos, A. (2017). CLIL, unequal working conditions and neoliberal subjectivities in a state secondary school. Language Policy, 174), 479-499. https://doi.org/10.1007/s10993-017-9451-5

Coonan, C. M. (2007). Insider views of the CLIL class through teacher selfobservation-introspection. International Journal of Bilingual Education and Bilingualism, 10(5), 625-646. https://doi.org/10.2167/beb463.0

Coyle, D. (2008). Content and Language Integrated Learning: Towards a connected research agenda for CLIL pedagogies. International Journal of Bilingual Education and Bilingualism, 10(5), 543-562. https://doi.org/10.2167/beb459.0

Dallinger, S., K. Jonkmann, J. Hollm \& Fiege, C. (2016). The effect of content and language integrated learning on students' English and history competences. Learning and Instruction, 41, 23-31. https://doi.org/10.1016/j.learninstruc.2015.09.003

De Graaf, R., Koopman, G. J., Anikina, Y. \& Westhoff, G. (2007). An observation tool for effective L2 pedagogy in Content and Language Integrated Learning (CLIL). International Journal of Bilingual Education and Bilingualism, 10(5), 603-624. https://doi.org/10.2167/beb462.0

European Commission (2013). First European Survey of Language Competence. Retrieved from:

$\underline{\text { http://ec.europa.eu/dgs/education_culture/repository/languages/po }}$ licy/strategic-framework/documents/language-survey-finalreport_en.pdf

Fernández-Sanjurjo, J., Fernández-Costales, A. \& Arias Blanco, J. M. (2017) Analysing students' content-learning in science in CLIL vs. nonCLIL programmes: empirical evidence from Spain. International Journal of Bilingual Education and Bilingualism, 22(6), 661-674. https://doi.org/10.1080/13670050.2017.1294142 
Heras, A., \& Lasagabaster, D. (2015). The impact of CLIL on affective factors and vocabulary learning. Language Teaching Research, 19(1), 70-88. https://doi.org/10.1177/1362168814541736

Hüttner, J., Dalton-Puffer, C. \& Smit, U. (2013). The power of beliefs: Lay theories and their influence on the implementation of CLIL programmes. International Journal of Bilingual Education and Bilingualism, 16(3), 267-284. https://doi.org/10.1080/13670050.2013.777385

Jäppinen, A. K. (2005). Thinking and Content Learning of Mathematics and Science as Cognitional Development in Content and Language Integrated Learning (CLIL): Teaching through a Foreign Language in Finland. Language and Education, 19(2), 147-168. https://doi.org/10.1080/09500780508668671

Junta de Andalucía (2011). Profundiza. Retrieved from: http://profundiza.org/ Lasagabaster, D. \& García, O. (2014). Translanguaging: Towards a dynamic model of bilingualism at school. Culture and Education, 26(3), 557572. https://doi.org/10.1080/11356405.2014.973671

Lorenzo, F. \& Trujillo, F. (2017). Languages of schooling in European policymaking: present state and future outcomes. European Journal of Applied Linguistics, 5, 177- 199. https://doi.org/10.1515/eujal-2017$\underline{0007}$

Lorenzo, F. (2017). Historical literacy in bilingual settings: Cognitive academic language in L2 history narratives. Linguistics and Education, 37, 32-41. https://doi.org/10.1016/j.linged.2016.11.002

Lorenzo, F. (Ed.). (2019). Educación Bilingüe en Andalucía. Informe de Gestión, Competencias y Organización. Agencia Andaluza de Evaluación Educativa. Consejería de Educación. Junta de Andalucía. Retrieved from:

http://www.juntadeandalucia.es/educacion/agaeve/docs/publicacio nes/InformeBilinguismo.pdf

Lorenzo, F., Casal, S. \& Moore, P. (2009). The Effects of Content and Language Integrated Learning in European Education: Key Findings from the Andalusian Bilingual Sections Evaluation Project. Applied Linguistics, 31(3), 418-442. https://doi.org/10.1093/applin/amp041 
One generation after the bilingual turn: results from a large...

Moore, P. \& Lorenzo, F. (2015). Task-based learning and content and language integrated learning materials design: process and product. The Language Learning Journal, 43(3), 334 -357. https://doi.org/10.1080/09571736.2015.1053282

OECD (2003). Education at a Glance: OECD Indicators. Paris: OECD Publishing. https://doi.org/10.1787/eag-2003-8-en

OECD (2014). New Insights from TALIS 2013: Teaching and Learning in Primary and Upper Secondary Education. Paris: OECD Publishing. https://doi.org/10.1787/9789264226319-en

OECD (2018). PISA for Development Assessment and Analytical Framework: Reading, Mathematics and Science. Paris: OECD Publishing. https://doi.org/10.1787/9789264305274-en

Pavón, V. \& Rubio, F. (2010). Teachers' concerns and uncertainties about the introduction of CLIL programmes. Porta Linguarium, 14, 4558.

Pavón, V., Ávila, J., Gallego, A. \& Espejo, R. (2014). Strategic and organisational considerations in planning CLIL: A study on the coordination between content and language teachers. International Journal of Bilingual Education and Bilingualism, 18(4), 409-425. https://doi.org/10.1080/13670050.2014.909774

Pérez, A., Lorenzo, F. \& Pavón, V. (2016). European bilingual models beyond lingua franca. Key findings from CLIL French programs. Language Policy, 15, 485-504. https://doi.org/10.1007/s10993-0159386-7

Rascón, D. \& Bretones, C. M. (2018). Socioeconomic Status and its Impact on Language and Content Attainment in CLIL Contexts. Porta Linguarum, 29, 115-135.

Relaño-Pastor, A. M. (2015). The commodification of English in 'Madrid, comunidad bilingüe': Insights from the CLIL classroom. Language Policy, 14(2), 131-152. https://doi.org/10.1007/s10993-014-9338-7

Relaño-Pastor, A. M. (2018) Narrative circularity, disputed transformations, and bilingual appropriations at a public school 'somewhere in La 
Mancha'. International journal of the sociology of language, 250, 87-112. https://doi.org/10.1515/ijsl-2017-0057

Ruiz de Zarobe, Y., Sierra, J. M. \& Gallardo del Puerto, F. (eds.) (2011) Content and foreign language integrated learning. Contributions to multilingualism in European contexts. Frankfurt am Main: Peter Lang. https://doi.org/10.3726/978-3-0351-0171-3

Skinnari, K., \& Bovellan, E. (2016). CLIL teachers' beliefs about integration and their professional roles: Perspectives from a European context. In T. Nikula, E. Dafouz, P. Moore, \& Smit, U. (Eds.), Conceptualising integration in CLIL and multilingual education (pp. 145-170). Bristol: Multilingual Matters. https://doi.org/10.21832/9781783096145-010

Sotoca, E. (2016). La repercusión del bilingüismo en el rendimiento académico en alumnos de colegios públicos de la Comunidad de Madrid. Revista Complutense de Educación, 25(2), 481-500.

Surmont, J., Craen, P., Struys, E. \& Somers, T. (2014). Evaluating a CLIL-student: Where to find the CLIL advantage. In R. Breeze, C. Pasamar, C. Saíz, \& C. Sala (Eds.), Integration of theory and practice in CLIL (pp. 55-72). Amsterdam: Rodopi. https://doi.org/10.1163/9789401210614_005 
One generation after the bilingual turn: results from a large...

\section{Appendix 1: Questionnaire for Content Teachers in Bilingual} Schools

\begin{tabular}{|c|c|}
\hline $\begin{array}{l}\text { 1. Express your level of satisfaction with the bilingual } \\
\text { coordination of content courses. }\end{array}$ & 123456 \\
\hline elaborated in your school. & 123456 \\
\hline $\begin{array}{l}\text { 3. If applicable, assess your level of participation in the } \\
\text { elaboration of the integrated plan for language and } \\
\text { content. }\end{array}$ & 123456 \\
\hline $\begin{array}{l}\text { 4. CTs work in a coordinate fashion in order to create or } \\
\text { adapt materials for Content and Language Integrated } \\
\text { Learning (CLIL). }\end{array}$ & 123456 \\
\hline $\begin{array}{l}\text { 5. Express your level of satisfaction with CLIL } \\
\text { methodology. }\end{array}$ & 123456 \\
\hline $\begin{array}{l}\text { 6. Assess the level of curricular adaptation undergone in } \\
\text { your course and the incorporation of L } 2 \text { cultural aspects. }\end{array}$ & 123456 \\
\hline $\begin{array}{l}\text { 7. The activities integrating content and L2 are } \\
\text { appropriate to students' levels and ages (difficulty, text } \\
\text { typologies, etc.). }\end{array}$ & 123456 \\
\hline 8. Th & 123456 \\
\hline $\begin{array}{l}\text { 9. Didactic, innovative and motivating resources are } \\
\text { used. }\end{array}$ & 123456 \\
\hline 10. ICI & 123456 \\
\hline $\begin{array}{l}\text { 11. The Bilingual Program makes it easier to develop } \\
\text { task-based learning and the integration of tasks between } \\
\text { school courses. }\end{array}$ & 123456 \\
\hline
\end{tabular}




\begin{tabular}{|c|c|}
\hline $\begin{array}{l}\text { 12. Select the percentage of L2 use that is made during } \\
\text { your lessons ( } 1 \text { : up to } 15 \%, 2: 30 \% ; 3: 50 \% ; 4: 65 \% ; 5: 80 \% \text {; } \\
\text { 6: } 100 \% \text { ). } \\
\text { If your answer ranged between } 1 \text { and } 3 \text { (lower than } 50 \% \text { ), } \\
\text { select the potential reasons: } \\
\text { _- Shortage of time for materials design. } \\
\text { _- Trouble in L2 oral fluency } \\
\text { _- The vast number contents of your subject. } \\
\text { _- Other reasons (please specify): }\end{array}$ & 123456 \\
\hline $\begin{array}{l}\text { 13. L2 is not only used to review contents prer } \\
\text { studied in Spanish, but also to work on new conter }\end{array}$ & 123456 \\
\hline $\begin{array}{l}\text { 14. Assess the amount of time that you have available for } \\
\text { materials design in the L } 2 \text {. }\end{array}$ & 123456 \\
\hline $\begin{array}{l}\text { 15. The CT coordinates with the language assistant in } \\
\text { order to plan students' tasks. }\end{array}$ & 123456 \\
\hline $\begin{array}{l}\text { 16. The language assistant collaborates actively in } \\
\text { materials design and the organization of activities. }\end{array}$ & 123456 \\
\hline $\begin{array}{l}\text { 17. The language assistant uses the L } 2 \text { throughout the } \\
\text { entire lesson. }\end{array}$ & 123456 \\
\hline $\begin{array}{l}\text { 18. Indicate how much you do the following activities in } \\
\text { order to update your L2 receptive skills (listening and } \\
\text { reading): }\end{array}$ & \\
\hline - Reading foreign press & 123456 \\
\hline - Reading literary works in the L2. & 123456 \\
\hline - Reading $\mathrm{r}$ & 123456 \\
\hline
\end{tabular}


One generation after the bilingual turn: results from a large...

- Attending L2 preparatory courses in order to obtain a 123456 language certification above the one you have (please specify which level).

-_ $\mathrm{C} 1$ _- $\mathrm{C} 2$

123456

- Watching interviews, programs, series or movies in

123456 their original version.

- Other reasons (please specify)

19. Indicate how much you do the following activities in order to update your L2 productive skills (speaking and writing):

- Attending L2 speaking lessons.

123456

- Regular exchanges with L2 native speakers.

123456

- Regular trips to L2-speaking countries.

123456

- Other reasons (please specify):

123456

20. Express your level of satisfaction with the 123456 improvement of your professional competences regarding the teaching of contents through the development of the five language skills.

21. The L2 use improves the level of acquisitions of your 123456 course's contents.

22. The CT perceives a satisfactory level of student 123456 implication and motivation in the learning of contents via the $\mathrm{L} 2$.

23. The CT believes the development of the Bilingual 123456 Program has improved students' L2 oral competences: listening and speaking. 


\begin{tabular}{|c|c|}
\hline $\begin{array}{l}\text { 24. The CT believes the development of the Bilingual } \\
\text { Program has improved students L2 written } \\
\text { competences: reading and writing. }\end{array}$ & 123456 \\
\hline $\begin{array}{l}\text { 25. The CT perceives an overall improvement of } \\
\text { students' academic performance thanks to their } \\
\text { participation in the Bilingual Program. }\end{array}$ & 123456 \\
\hline $\begin{array}{l}\text { 26. The evaluation of the teaching-learning process is } \\
\text { coherent with the work done in the CLIL didactic } \\
\text { sequences. }\end{array}$ & 123456 \\
\hline $\begin{array}{l}\text { 27. In accordance with the evaluation criteria defined in } \\
\text { the Educational Project, the language competence } \\
\text { achieved by students is taken into consideration during } \\
\text { the evaluation in order to improve their final results. }\end{array}$ & 123456 \\
\hline $\begin{array}{l}\text { 28. Express your overall satisfaction with the } \\
\text { development of the Bilingual Program in your school. }\end{array}$ & 123456 \\
\hline \multicolumn{2}{|c|}{$\begin{array}{l}\text { DIFFICULTIES ENCOUNTERED IN YOUR WORK AS A BILINGUAL } \\
\text { CONTENT TEACHER AND SUGGESTIONS FOR IMPROVEMENT*: }\end{array}$} \\
\hline *If it were necessary, write your answer in an addition & ece \\
\hline
\end{tabular}

First version received: March, 2020 Final version accepted: June, 2020 